\title{
Borrelia turcica sp. nov., isolated from the hard tick Hyalomma aegyptium in Turkey
}

\section{Correspondence \\ Toshiyuki Masuzawa \\ masuzawa@u-shizuoka-ken.ac.jp}

\author{
Ece S. Güner, ${ }^{1}$ Mutsumi Watanabe, ${ }^{2}$ Naoya Hashimoto, ${ }^{2}$ Teruki Kadosaka, ${ }^{3}$ \\ Yoshiaki Kawamura, ${ }^{4}$ Takayuki Ezaki, ${ }^{4}$ Hiroki Kawabata, ${ }^{5}$ Yasuyuki Imai, ${ }^{2}$ \\ Kazuhide Kaneda ${ }^{2,6}$ and Toshiyuki Masuzawa ${ }^{2}$ \\ ${ }^{1}$ Medical School, Yeditepe University, Istanbul, Turkey \\ ${ }^{2}$ Department of Microbiology and COE Program in the 21st Century, University of Shizuoka \\ School of Pharmaceutical Sciences, Shizuoka, 422-8526, Japan \\ ${ }^{3}$ Department of Parasitology, Aichi Medical University, Aichi, 480-1195, Japan \\ ${ }^{4}$ Department of Microbiology, School of Medicine, Gifu University, Gifu, 500-8705, Japan \\ ${ }^{5}$ Department of Bacteriology, National Institute of Infectious Diseases, Tokyo, 162-8640, Japan \\ ${ }^{6}$ Department of Food Science, Shizuoka Eiwa Gakuen University Junior College, Shizuoka, \\ 422-8005, Japan
}

Previously, a novel, fast-growing spirochaete was isolated from the hard tick Hyalomma aegyptium, which infests tortoises (Testudo graeca), by using Barbour-Stoenner-Kelly (BSK) II medium; the tick samples were taken from the Istanbul area in northwestern Turkey [Güner et al. (2003). Microbiology 149, 2539-2544]. Here is presented a detailed characterization of the spirochaete. Electron microscopy revealed that strain IST7 ${ }^{\top}$ is morphologically similar to other spirochaetes of the genus Borrelia and possesses 15 to 16 flagellae that emerge from both polar regions. PFGE analysis revealed the genome to comprise a linear chromosome of approximately $1 \mathrm{Mb}$; two large linear plasmids of approximately 145 and $140 \mathrm{~kb}$, and several small plasmids ranging from 50 to $20 \mathrm{~kb}$ in size were also found. The 16S rRNA gene sequence of this Borrelia isolate exhibited $99 \cdot 4$ to $99.8 \%$ identity with other strains isolated from $H$. aegyptium and less than $99 \%$ similarity with those of other Borrelia species. A phylogenetic tree, generated from 16S rRNA gene sequences, demonstrated that the spirochaete isolates from $\mathrm{H}$. aegyptium clustered together and branched off from both Lyme-disease-related and relapsing-fever-associated Borrelia species. A single copy of the rrs gene was detected in the genome of strain IST7 ${ }^{\top}$ by Southern hybridization. DNA-DNA hybridization results showed that strain IST7 ${ }^{\top}$ was distinct from Lyme-disease-related Borrelia, Borrelia burgdorferi and the relapsing-fever-associated species Borrelia hermsii. The $\mathrm{G}+\mathrm{C}$ content of strain $I S T 7^{\top}$ is 30.0 mol\%. From these genetic features, a novel Borrelia species, Borrelia turcica sp. nov., is proposed; the type strain is $I S T 7^{\top}(=\mathrm{JCM}$ $11958^{\top}=$ DSM $16138^{\top}$ ).
Lyme borreliosis and relapsing fever are caused by Borrelia species (Barbour \& Hayes, 1986). Lyme-disease-related Borrelia have been classified into at least 11 species (Masuzawa et al., 2001; Miyamoto \& Masuzawa, 2002) and are transmitted by hard ticks of the family Ixodes.

Abbreviations: BSK, Barbour-Stoenner-Kelly; CFE, constant-field electrophoresis.

The GenBank/EMBL/DDBJ accession numbers for the 16S rRNA gene sequences reported in this article are AB111849-AB111854.

Transmission electron micrographs, a PFGE profile, a two-dimensional gel electrophoresis profile, determination of the rrs copy number and a physical map of the DNA fragment containing the rrs gene of strain IST7 ${ }^{\top}$ are available as supplementary material in IJSEM Online.
Relapsing-fever-associated Borrelia species, including Borrelia coriaceae, are transmitted by soft ticks of the genus Ornithodoros. An avian borreliosis agent, Borrelia anserina, is also carried by soft ticks, Argas persicus. Other relapsing-fever-associated Borrelia species are Borrelia recurrentis, transmitted by the human body louse (Pediculus humanus), and a bovine borreliosis agent, Borrelia theileri (Armstrong et al., 1996), transmitted by Rhipicephalus evertsi and Boophilus spp. (Barbour \& Hayes, 1986). Furthermore, Borrelia miyamotoi (Fukunaga et al., 1995), 'Borrelia lonestari' (Barbour et al., 1996) and B. miyamotoi-like Borrelia (Fraenkel et al., 2002) carried by hard ticks, Ixodes persulcatus in Japan, Amblyomma americanum in the United States and Ixodes ricinus in 
Sweden, respectively, are classified within the relapsingfever-associated Borrelia. Previously, we have reported the isolation of six pure cultures of a novel, fast-growing spirochaete from the hard tick Hyalomma aegyptium: tick samples were taken from a summer resort in the Istanbul area of Turkey in the summer of 2000 and the novel spirochaete was isolated by using Barbour-Stoenner-Kelly (BSK) II medium (Güner et al., 2003). The optimal growth temperature of the spirochaete in BSK II medium was between 34 and $37^{\circ} \mathrm{C}$, and doubling times at 34 and $37^{\circ} \mathrm{C}$ were $5 \cdot 3$ and $5 \cdot 1 \mathrm{~h}$, respectively. The six strains were morphologically similar to other Borrelia species and contained a $41 \mathrm{kDa}$ flagellin protein. Analysis of flaB sequences suggested that the unique spirochaete belonged to the genus Borrelia, but differed from previously described species (Güner et al., 2003). The aim of the present study was to characterize the novel, fast-growing spirochaete by using $16 \mathrm{~S}$ rRNA gene sequence data, DNA-DNA relatedness, $\mathrm{G}+\mathrm{C}$ content and chromosome and plasmid organization. Based on the results of these analyses, we propose a novel species of the genus Borrelia, Borrelia turcica sp. nov.

Strain IST ${ }^{\mathrm{T}}$ was purified from a colony formed on BSK II agar medium (Barbour, 1984) at $34^{\circ} \mathrm{C}$ under $5 \%$ carbon dioxide. To determine the number of flagellae, crosssections of strain $\mathrm{IST}^{\mathrm{T}}$ were prepared as described previously (Masuzawa et al., 2001). Photomicrographs were taken with a Hitachi H-7000 electron microscope at an acceleration voltage of $75 \mathrm{kV}$. Chromosome and plasmid organization was examined by PFGE as described by Cutler et al. (1997). The DNA contained in an agarose plug was run at $150 \mathrm{~V}$ with the pulse time ramped from 5 to $125 \mathrm{~s}$ for a total of $36 \mathrm{~h}$, at $150 \mathrm{~V}$ with the pulse time ramped from 0.5 to $20 \mathrm{~s}$ for a total of $36 \mathrm{~h}$ or at $200 \mathrm{~V}$ with a pulse time of $2 \mathrm{~s}$ for $18 \mathrm{~h}$. Furthermore, to investigate the structure of the chromosome and plasmids, twodimensional gel electrophoresis was carried out as described by Ferdows et al. (1996). The DNA contained in an agarose plug was electrophoresed in the first dimension by PFGE at $200 \mathrm{~V}$ with the pulse time ramped from 0.5 to $15 \mathrm{~s}$ for $24 \mathrm{~h}$ in $0.5 \times$ TBE. After the PFGE, the gel was placed in a horizontal unit and set perpendicular to the position of the first-dimension gel. Constant-field electrophoresis (CFE) was performed for $3.5 \mathrm{~h}$ at $80 \mathrm{~V}$ in $0.5 \times$ TBE. Template DNAs for $16 \mathrm{~S}$ rRNA gene sequencing were prepared as described previously (Masuzawa et al., 1996). Aliquots $(0.5 \mathrm{ml})$ of cultures were washed. The cells were resuspended in $100 \mu \mathrm{l}$ of water and boiled at $100{ }^{\circ} \mathrm{C}$ for $10 \mathrm{~min}$. After centrifugation at $10000 \mathrm{~g}$ for $5 \mathrm{~min}$, the supernatant was collected as template DNA. The $16 \mathrm{~S}$ rRNA gene sequences were amplified with the primers 16SF1, corresponding to the $5^{\prime}$ end of the $16 \mathrm{~S}$ rRNA gene $\left(5^{\prime}\right.$ ATA ACG AAG AGT TTG ATC CTG GC-3'), and 16SR, corresponding to the $3^{\prime}$ end of the $16 \mathrm{~S}$ rRNA gene ( $5^{\prime}$-CAG CCG CAC TTT CCA GTA CG-3'), by PCR (Masuzawa et al., 2001). The amplified 16S rRNA gene fragments (about $1350 \mathrm{bp}$ ) were purified by using a DNA purification column (Microcon-PCR; Millipore). For DNA sequencing, the same sequence primers, labelled with Texas-red (Proligo), were used. The DNA cycle sequencing reaction was performed using the Thermo Sequenase pre-mixed cycle sequencing kit (Amersham Biosciences) according to the manufacturer's recommendation. DNA sequences were determined using a SQ5500EL DNA-sequencer (Hitachi). CLUSTAL_X software (Thompson et al., 1997) was used to align the sequences, and the phylogenetic distance was calculated by using the neighbour-joining method (Saitou \& Nei, 1987) and UPGMA method with Genetyx-Mac version 10. To determine DNA-DNA homology values, DNAs purified from strain $\mathrm{IST}^{\mathrm{T}}$ and representative Borrelia species, Borrelia hermsii strain HS1 and Borrelia burgdorferi strain $\mathrm{B} 31^{\mathrm{T}}$ as described previously (Kawabata et al., 1993) were subjected to microplate hybridization using photobiotin-labelled DNA (Ezaki et al., 1988; Masuzawa et al., 2001). Briefly, DNA coated onto microplates was pre-treated with prehybridization solution $[2 \times$ SSC $(1 \times$ SSC is $0 \cdot 15 \mathrm{M} \mathrm{NaCl}$ plus $0.015 \mathrm{M}$ sodium citrate), $5 \times$ Denhardt's solution and $50 \%$ formamide] containing $200 \mu \mathrm{g}$ denatured salmon sperm DNA ml${ }^{-1}$. Photobiotin-labelled DNA prepared as reported previously (Ezaki et al., 1989) was hybridized in the presence $50 \%$ formamide at $26^{\circ} \mathrm{C}$ (Blüthmann et al., 1973). The $\mathrm{G}+\mathrm{C}$ content of DNA was determined by HPLC (Noguchi et al., 1988), using a DNA-GC kit (Seikagaku-kogyo). The copy number of the 16S rRNA gene was determined by Southern blot analysis. To prepare the DNA probes, primers 8UA (5'-AGAGTTTGATCCTGGCTCAG-3'; Komatsu et al., 1996), 16SMR (5'CCTCCCTTACGGGTTAGAG-3'; GenBank accession no. M88329, position 1452-1435) and 350R (5'-CTGCTGCCTCCCGTAG-3'; Sawada et al., 1993) were used for amplification of part of the rrs gene (Fig. IV, available as supplementary material in IJSEM Online). The products amplified by using $8 \mathrm{UA} / 16 \mathrm{SMR}$ or $8 \mathrm{UA} / 350 \mathrm{R}$ were used as probe $\mathrm{A}$ and probe $\mathrm{B}$, respectively. The purified genomic DNA was digested with restriction enzymes and separated on a $0.8 \%$ agarose gel and transferred to a Hybond- $\mathrm{N}^{+}$ nylon membrane (Amersham Biosciences). The hybridization was performed with the probes labelled by an ECL Direct Nucleic Acid Labelling and Detection System (Amersham Biosciences).

Spirochaetes isolated from $H$. aegyptium were slender and helically shaped (Fig. I, available as supplementary material in IJSEM Online). The length of the cells varied from 10 to $25 \mu \mathrm{m}$, and the diameter was $0 \cdot 2 \mu \mathrm{m}$ to $0 \cdot 28 \mu \mathrm{m}$ (Güner et al., 2003). Eight to 23 flagellae were observed at both ends. The average number of flagellae observed was 15 to 16 .

Strain $\mathrm{IST7}^{\mathrm{T}}$ had chromosomal DNA that migrated as a $1 \mathrm{Mb}$ band similar to that of other borrelia, B. hermsii, Borrelia parkeri, Borrelia turicatae and B. burgdorferi on the PFGE analysis (Fig. IIa, available as supplementary material in IJSEM Online). Furthermore, with a pulse time of $2 \mathrm{~s}$, or ramped from 0.5 to $20 \mathrm{~s}$, a relatively small plasmid was separated. Strain IST7 ${ }^{\mathrm{T}}$ had plasmids of about 145 and $140 \mathrm{~kb}$ in size, and at least seven plasmids smaller than $50 \mathrm{~kb}$ 
(Fig. IIb, c, available as supplementary material in IJSEM Online). The genomic organization of spirochaetes in the genus Borrelia is unique in that the chromosome and most plasmids are linear (Barbour \& Hayes, 1986). Twodimensional gel electrophoresis was performed to investigate the genomic structure of strain IST7 ${ }^{\mathrm{T}}$. All DNA bands of strain $\mathrm{IST7}^{\mathrm{T}}$ with chromosomal DNA migrated in the second-dimension gel (Fig. III, available as supplementary material in IJSEM Online). An open circular DNA may enter the gel in PFGE of the first dimension, but it will be arrested in CFE of the second dimension (Ferdows \& Barbour, 1989; Serwer \& Allen, 1984). In this experiment, the $1 \mathrm{Mb}$ chromosome and 140 and $145 \mathrm{~kb}$ plasmids of strain IST7 ${ }^{\mathrm{T}}$ behaved in a similar manner to the linear DNA molecule of Saccharomyces cerevisiae and of B. hermsii in the seconddimension gel. Therefore, the results indicated that these were linear DNA molecules.

It was reported that there was a single copy of the rrs gene in spirochaetes of the genus Borrelia (Schwartz et al., 1992). We determined whether the rrs gene of the Hyalommaoriginating isolate was present as a single copy by Southern blot hybridization with two probes that were complementary to a specific sequence in the gene. Restriction enzymes that cleave inside the gene (strain IST7 ${ }^{\mathrm{T}}$; GenBank accession no. AB111849, this study) were selected for the analysis. The results using HindIII, KpnI and $\mathrm{XbaI}$ and the restriction map containing the rrs gene are shown in Fig. IV (available as supplementary material in IJSEM Online). DNA fragments of 5.7 and $3.7 \mathrm{~kb}$ were hybridized with probe $\mathrm{A}$ in the $\mathrm{Xba \textrm {I }}$ digestion, but the $3.7 \mathrm{~kb}$ band was not observed with probe B. DNA fragments of $9 \cdot 4$ and $7 \cdot 8 \mathrm{~kb}$ were hybridized with probe $\mathrm{A}$ in the $K p n \mathrm{I}$ digestion, but the $7 \cdot 8 \mathrm{~kb}$ band was absent when probe $\mathrm{B}$ was used. DNA fragments of 1.4 and $1.9 \mathrm{~kb}$ were hybridized with probe $\mathrm{A}$ in the HindIII digestion, whereas the $1.9 \mathrm{~kb}$ band was absent when probe $B$ was used. A single band ranging from 4.5 to $20 \mathrm{~kb}$ in length was observed with probe A when restriction enzymes BamHI, BglII, NcoI, NheI, SpeI, SphI and XhoI, which did not cleave inside of the rrs gene, were used (data not shown). These data, together with the results of rrs gene sequencing, indicate that a single copy of $r r s$ is present in the genome.

A phylogenetic tree, based on 16S rRNA gene sequences, was constructed by using the neighbour-joining method (Fig. 1). The phylogenetic relationship among relapsingfever-associated Borrelia species and Lyme-disease-related Borrelia species was reported previously by Ras et al. (1996). The 16S rRNA gene sequences of six strains, ISTF1, IST2, ISTF2, IST4, IST6 and IST7 ${ }^{\mathrm{T}}$, isolated from $H$. aegyptium formed a monophyletic cluster and showed similarity values ranging from $99 \cdot 4$ to $99 \cdot 8 \%$. Interestingly, spirochaetes isolated from $H$. aegyptium formed a separate branching root from both Lyme-disease-related Borrelia species and relapsing-fever-associated Borrelia species (similarity values ranging from 93.9 to $98 \cdot 2 \%$ ). A similar tree on the topology of branches was constructed by using the UPGMA

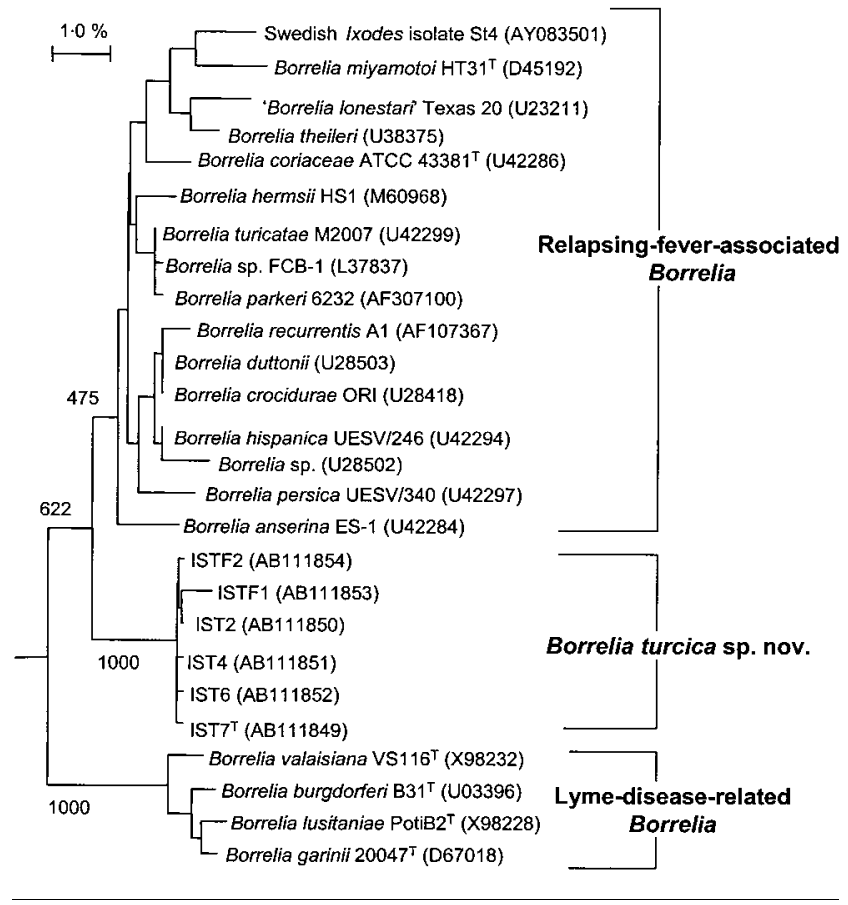

Fig. 1. Phylogenetic tree based on $16 \mathrm{~S}$ rRNA gene sequence data. Sequences of strains ISTF1, ISTF2, IST2, IST4, IST6 and ${ }_{\text {IST7 }}{ }^{\top}$ were determined in this study. Accession numbers are shown in parentheses. Bar, $1.0 \%$ sequence divergence. Spirochaeta litoralis (GenBank accession no. M88723) was used as an outgroup (not shown).

method (data not shown). Our findings suggested that the Hyalomma-originating isolates were unique and phylogenetically divergent from both Lyme-disease-related and relapsing-fever-associated Borrelia species. Furthermore, the level of DNA relatedness in strain IST7 ${ }^{\mathrm{T}}$ was less than $20 \%$ when compared with the Lyme-disease agent, B. burgdorferi, or the relapsing-fever agent, $B$. hermsii. These results indicated that strain $\mathrm{IST}^{\mathrm{T}}$ was different from $B$. burgdorferi and B. hermsii. The $\mathrm{G}+\mathrm{C}$ content of the DNA of strain $\mathrm{IST}^{\mathrm{T}}$ was $30 \cdot 0 \mathrm{~mol} \%$. The $\mathrm{G}+\mathrm{C}$ content of the DNA of the other borrelia species, B. hermsii, B. parkeri, B. turicatae and $B$. burgdorferi, examined in this study was $30 \cdot 6,30 \cdot 6,29 \cdot 4$ and $29 \cdot 0 \mathrm{~mol} \%$, respectively. These values were similar to those reported previously (Barbour \& Hayes, 1986; Hyde \& Johnson, 1984; Johnson et al., 1984; Kawabata et al., 1993; Schmid et al., 1984). Based on these findings, and the results of $f l a B$ and phenotypic analyses reported previously (Güner et al., 2003), a novel Borrelia species, Borrelia turcica sp. nov., is proposed.

\section{Description of Borrelia turcica sp. nov.}

Borrelia turcica (tur.ci'ca. N.L. fem. adj. turcica referring to Turkey, the country in which the species was isolated).

Isolated from the hard tick Hyalomma aegyptium from samples collected in Istanbul, Turkey. Morphology is as 
described previously for the genus (Barbour \& Hayes, 1986; Güner et al., 2003). Length of the cells is variable, about $10-25 \mu \mathrm{m}$, and the diameter is $0 \cdot 2-0 \cdot 28 \mu \mathrm{m}$, with eight to 23 flagellae. The average number of flagellae is 15 to 16 . The optimal growth temperature in BSK II medium is between 34 and $37^{\circ} \mathrm{C}$; cells can grow at $39^{\circ} \mathrm{C}$. Doubling times at 34 and $37^{\circ} \mathrm{C}$ are $5 \cdot 3$ and $5 \cdot 1 \mathrm{~h}$, respectively. Contains a $41 \mathrm{kDa}$ protein that is reactive with mAb H9724 (Barbour et al., 1986), which is specific to the flagellin of Borrelia species.

The type strain is $\operatorname{IST}^{\mathrm{T}}\left(=\mathrm{JCM} 11958^{\mathrm{T}}=\mathrm{DSM} 16138^{\mathrm{T}}\right)$. Its $\mathrm{G}+\mathrm{C}$ content is $30 \cdot 0 \mathrm{~mol} \%$.

\section{Acknowledgements}

This study was supported in part by a Grant-in-Aid for Scientific Research B (No. 13576014) from the Japan Society for the Promotion of Science (JSPS).

\section{References}

Armstrong, P. M., Rich, S. M., Smith, R. D., Hartl, D. L., Spielman, A. \& Telford, S. R., III (1996). A new Borrelia infecting Lone Star ticks. Lancet 347, 67-68.

Barbour, A. G. (1984). Isolation and cultivation of Lyme disease spirochetes. Yale J Biol Med 57, 521-554.

Barbour, A. G. \& Hayes, S. F. (1986). Biology of Borrelia species. Microbiol Rev 50, 381-400.

Barbour, A. G., Hayes, S. F., Heiland, R. A., Schrumpf, M. E. \& Tessier, S. L. (1986). A Borrelia-specific monoclonal antibody binds to a flagellar epitope. Infect Immun 52, 549-554.

Barbour, A. G., Maupin, G. O., Teltow, G. J., Carter, C. J. \& Piesman, J. (1996). Identification of an uncultivable Borrelia species in the hard tick Amblyomma americanum: possible agent of a Lyme disease-like illness. J Infect Dis 173, 403-409.

Blüthmann, H., Brück, D., Hübner, L. \& Schöffski, A. (1973). Reassociation of nucleic acids in solutions containing formamide. Biochem Biophys Res Commun 50, 91-97.

Cutler, S. J., Moss, J., Fukunaga, M., Wright, D. J. M., Fekade, D. \& Warrell, D. (1997). Borrelia recurrentis characterization and comparison with relapsing-fever, Lyme-associated, and other Borrelia spp. Int J Syst Bacteriol 47, 958-968.

Ezaki, T., Takeuchi, N., Liu, S. L., Kai, A., Yamamoto, H. \& Yabuuchi, E. (1988). Small-scale DNA preparation for rapid genetic identification of Campylobacter species without radioisotope. Microbiol Immunol 32, 141-150.

Ezaki, T., Hashimoto, Y. \& Yabuuchi, E. (1989). Fluorometric deoxyribonucleic acid-deoxyribonucleic acid hybridization in microdilution wells as an alternative to membrane filter hybridization in which radioisotopes are used to determine genetic relatedness among bacterial strains. Int J Syst Bacteriol 39, 224-229.

Ferdows, M. S. \& Barbour, A. G. (1989). Megabase-sized linear DNA in the bacterium Borrelia burgdorferi, the Lyme disease agent. Proc Natl Acad Sci U S A 86, 5969-5973.

Ferdows, M. S., Serwer, P., Griess, G. A., Norris, S. J. \& Barbour, A. G. (1996). Conversion of a linear to a circular plasmid in the relapsing fever agent Borrelia hermsii. J Bacteriol 178, 793-800.

Fraenkel, C. J., Garpmo, U. \& Berglund, J. (2002). Determination of novel Borrelia genospecies in Swedish Ixodes ricinus ticks. J Clin Microbiol 40, 3308-3312.
Fukunaga, M., Takahashi, Y., Tsuruta, Y., Matsushita, O., Ralph, D., McClelland, M. \& Nakao, M. (1995). Genetic and phenotypic analysis of Borrelia miyamotoi sp. nov., isolated from the ixodid tick Ixodes persulcatus, the vector for Lyme disease in Japan. Int J Syst Bacteriol 45, 804-810.

Güner, E. S., Hashimoto, N., Kadosaka, T., Imai, Y. \& Masuzawa, T. (2003). A novel, fast-growing Borrelia sp. isolated from the hard tick Hyalomma aegyptium in Turkey. Microbiology 149, 2539-2544.

Hyde, F. W. \& Johnson, R. C. (1984). Genetic relationship of Lyme disease spirochetes to Borrelia, Treponema, and Leptospira. J Clin Microbiol 20, 151-154.

Johnson, R. C., Schmid, G. P., Hyde, F. W., Steigerwalt, A. G. \& Brenner, D. J. (1984). Borrelia burgdorferi sp. nov.: etiologic agent of Lyme disease. Int J Syst Bacteriol 34, 496-497.

Kawabata, H., Masuzawa, T. \& Yanagihara, Y. (1993). Genomic analysis of Borrelia japonica sp. nov. isolated from Ixodes ovatus in Japan. Microbiol Immunol 37, 843-848.

Komatsu, M., Shimakawa, K., Aihara, M., Matsuo, S. \& Ezaki, T. (1996). Detection and identification method of three mycobacterium species and genus specific detection by polymerase chain reaction and DNA hybridization with alkaline phosphatase labeled oligonucleotide probe. Kansenshogaku Zasshi 70, 141-150 (in Japanese).

Masuzawa, T., Komikado, T., Iwaki, A., Suzuki, H., Kaneda, K. \& Yanagihara, Y. (1996). Characterization of Borrelia sp. isolated from Ixodes tanuki, I. turdus, and I. columnae in Japan by restriction fragment length polymorphism of $r r f(5 S)-r r l$ (23S) intergenic spacer amplicons. FEMS Microbiol Lett 142, 77-83.

Masuzawa, T., Takada, N., Kudeken, M., Fukui, T., Yano, Y., Ishiguro, F., Kawamura, Y., Imai, Y. \& Ezaki, T. (2001). Borrelia sinica sp. nov., a Lyme disease-related Borrelia species isolated in China. Int J Syst Evol Microbiol 51, 1817-1824.

Miyamoto, K. \& Masuzawa, T. (2002). Ecology of Borrelia burgdorferi sensu lato in Japan and East Asia. In Lyme Borreliosis, Biology, Epidemiology and Control, pp. 201-222. Edited by J. S. Gray, O. Kahl, R. S. Lane, \& G. Stanek. Oxford: CABI Publishing.

Noguchi, T., Kumagai, M. \& Kuninaka, A. (1988). Analysis of base composition of sequenced DNA's by high performance liquid chromatography of their nuclease p1 hydrolysate. Agric Biol Chem 52, 2355-2356.

Ras, N. M., Lascola, B., Postic, D., Cutler, S. J., Rodhain, F., Baranton, G. \& Raoult, D. (1996). Phylogenesis of relapsing fever Borrelia spp. Int J Syst Bacteriol 46, 859-865.

Saitou, N. \& Nei, M. (1987). The neighbor-joining method: a new method for reconstructing phylogenetic trees. Mol Biol Evol 4, 406-425.

Sawada, H., leki, H., Oyaizu, H. \& Matsumoto, S. (1993). Proposal for rejection of Agrobacterium tumefaciens and revised descriptions for the genus Agrobacterium and for Agrobacterium radiobacter and Agrobacterium rhizogenes. Int J Syst Bacteriol 43, 694-702.

Schmid, G. P., Steigerwalt, A. G., Johnson, S. E., Barbour, A. G., Steere, A. C., Robinson, I. M. \& Brenner, D. J. (1984). DNA characterization of the spirochete that causes Lyme disease. J Clin Microbiol 20, 155-158.

Schwartz, J. J., Gazumyan, A. \& Schwartz, I. (1992). rRNA gene organization in the Lyme disease spirochete, Borrelia burgdorferi. $J$ Bacteriol 174, 3757-3765.

Serwer, P. \& Allen, J. L. (1984). Conformation of double-stranded DNA during agarose gel electrophoresis: fractionation of linear and circular molecules with molecular weights between $3 \times 10^{6}$ and $26 \times 10^{6}$. Biochemistry 23, 922-927.

Thompson, J. D., Gibson, T. J., Plewniak, F., Jeanmougin, F. \& Higgins, D. G. (1997). The CLUSTAL_X windows interface: flexible strategies for multiple sequence alignment aided by quality analysis tools. Nucleic Acids Res 25, 4876-4882. 